\title{
Genetic diagnosis of Beckwith Wiedemann syndrome and Silver-Russell syndrome
}

\author{
Yoo-Mi Kim², Gu-Hwan Kim, Beom Hee Lee ${ }^{1,2}$, Jin-Joo Lee', Seong-Hoon Choi ${ }^{1}$, Ju Yeon Lee ${ }^{1}$, Han-Wook Yoo ${ }^{1,2}$ \\ From 7th APPES Biennial Scientific Meeting \\ Nusa Dua, Bali. 14-17 November 2012
}

Beckwith-Wiedemann syndrome (BWS) is fetal overgrowth syndrome, whereas Silver-Russell syndrome (SRS) is characterized by pre- or postnatal growth retardation. BWS and SRS share molecular epigenetic defects in chromosome $11 \mathrm{p} 15$, where two imprinting centers, LIT1-differentially methylated region (MDR) and H19DMR, exist. A small number of patients with SRS harbor maternal uniparental disomy of chromosome $7 \mathrm{q}$ as well. Extensive genetic analyses including methylation specific (MS) PCR-RFLP, MS-MLPA, microsatellite markers or MS-pyrosequencing analysis were performed using genomic DNA obtained from peripheral leukocytes to identify the epigenetic detects in patients with BWS and SRS. Ten out of 14 BWS patients (71.4\%) showed hypomethylation in LIT1-DMR. One BWS patient harbored hypermethylation in H19-DMR (7.1\%). Two BWS patients had both H19-DMR and LIT1-DMR defects, one of whom has paternal UPD at chr. 11 (14.3\%). Eleven out of 13 SRS patients (78.6 \%) showed hypomethylation in H19-DMR. One SRS patient (6.7\%) had UPD at 7q. With MS-pyrosequencing analysis, epigenetic defects were identified in $93.1 \%$ of BWS patients and $85.7 \%$ of SRS patients. These positive rates are higher than previously reported positive rates, $80 \%$ in BWS and 50\% in SRS. In addition, with MS-pyrosequencing analyses, quantification of methylation defects was available, which could identify partial methylation defects that were not revealed by MS-PCR-RFLP or MSMLPA. The validity of MS-pyrosequencing method for the genetic diagnosis of BWS or SRS is needed to be investigated in a large patient cohort.

${ }^{2}$ Department of Pediatrics, Asan Medical Center, University of Ulsan College of Medicine, Seoul, Korea

Full list of author information is available at the end of the article
Authors' details

'Medical Genetics Center, University of Ulsan College of Medicine, Seoul, Korea. ${ }^{2}$ Department of Pediatrics, Asan Medical Center, University of Ulsan College of Medicine, Seoul, Korea.

Published: 3 October 2013

doi:10.1186/1687-9856-2013-S1-044

Cite this article as: Kim et al:: Genetic diagnosis of Beckwith

Wiedemann syndrome and Silver-Russell syndrome. International Journal of Pediatric Endocrinology 2013 2013(Suppl 1):O44.
Submit your next manuscript to BioMed Central and take full advantage of:

- Convenient online submission

- Thorough peer review

- No space constraints or color figure charges

- Immediate publication on acceptance

- Inclusion in PubMed, CAS, Scopus and Google Scholar

- Research which is freely available for redistribution
() Biomed Central

\section{Biomed Central}

